\title{
CD36 Gene
}

National Cancer Institute

\section{Source}

National Cancer Institute. CD36 Gene. NCI Thesaurus. Code C38191.

This gene is involved in the regulation of cellular transport and adhesion. 